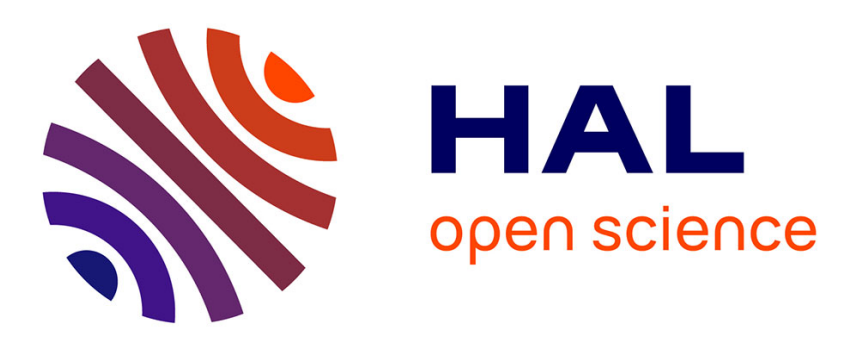

\title{
Concentration effect on the scintillation properties of Sol-Gel derived LuBO3 doped with Eu3+ and Tb3+.
}

Christelle Mansuy, Jean-Marie Nedelec, Christophe Dujardin, Rachid Mahiou

\section{To cite this version:}

Christelle Mansuy, Jean-Marie Nedelec, Christophe Dujardin, Rachid Mahiou. Concentration effect on the scintillation properties of Sol-Gel derived LuBO3 doped with Eu3+ and Tb3+.. Optical Materials, 2007, 29, pp.697-702. 10.1016/j.optmat.2005.10.017 . hal-00174446

\section{HAL Id: hal-00174446 https://hal.science/hal-00174446}

Submitted on 24 Sep 2007

HAL is a multi-disciplinary open access archive for the deposit and dissemination of scientific research documents, whether they are published or not. The documents may come from teaching and research institutions in France or abroad, or from public or private research centers.
L'archive ouverte pluridisciplinaire HAL, est destinée au dépôt et à la diffusion de documents scientifiques de niveau recherche, publiés ou non, émanant des établissements d'enseignement et de recherche français ou étrangers, des laboratoires publics ou privés. 


\title{
Concentration effect on the scintillation properties of
}

\section{Sol-Gel derived $\mathrm{LuBO}_{3}$ doped with $\mathrm{Eu}^{3+}$ and $\mathrm{Tb}^{3+}$.}

\author{
C. Mansuy ${ }^{1}$, J.M. Nedelec ${ }^{1 *}$, C. Dujardin ${ }^{2}$ and R. Mahiou ${ }^{1}$ \\ ${ }^{1}$ Laboratoire des Matériaux Inorganiques, CNRS UMR 6002, Université Blaise Pascal et \\ Ecole Nationale Supérieure de Chimie de Clermont-Ferrand, \\ 63177 Aubière cedex, France \\ ${ }^{2}$ Laboratoire de Physico-Chimie des Matériaux Luminescents, CNRS UMR 5620 \\ Université Claude Bernard, 10 rue A.M. Ampère 69622 Villeurbanne Cedex, France.
}

\footnotetext{
* Corresponding author : Dr J.M. Nedelec Laboratoire des Matériaux Inorganiques UMR 6002 Université Blaise Pascal, 24 Avenue des Landais 63177 Aubière Cedex, FRANCE

E-mail : j-marie.nedelec@univ-bpclermont.fr
} 


\begin{abstract}
$\mathrm{Lu}_{1-\mathrm{x}} \mathrm{Eu}_{\mathrm{x}} \mathrm{BO}_{3}$ and $\mathrm{Lu}_{1-\mathrm{x}} \mathrm{Tb}_{\mathrm{x}} \mathrm{BO}_{3}$ powders have been prepared by a sol-gel process with $0<\mathrm{x}<0.15$ for $\mathrm{Eu}^{3+}$ and $0<\mathrm{x}<0.05$ for $\mathrm{Tb}^{3+}$. The purity of powders has been verified by X-Ray diffraction and the results confirm that all the materials have the vaterite type even if the calcination has been performed at $800^{\circ} \mathrm{C}$. Furthermore, the solid solution for $\mathrm{LuBO}_{3}$ vaterite is observed up to $\mathrm{x}=0.15$ and $\mathrm{x}=0.05$ for europium and terbium ions respectively. So doping with $\mathrm{Eu}^{3+}$ or $\mathrm{Tb}^{3+}$ ions does not affect the structure. These materials have also been analyzed by Fourier Transform Infra Red Spectroscopy. The morphology of the powders has been studied by Scanning Electron Microscopy and shows a very nice morphology with small spherical particles with narrow size distribution. Optical properties have then been studied to confirm the effective substitution of $\mathrm{Eu}^{3+}$ or $\mathrm{Tb}^{3+}$ for $\mathrm{Lu}^{3+}$ ions and to determine the materials scintillation performances. The optima, in term of scintillation yield, are obtained for $\mathrm{Eu}^{3+}$ and $\mathrm{Tb}^{3+}$ concentration of $\mathrm{x}=0.05$ in both cases. The afterglows have also been measured and confirm the potentiality of these materials as scintillators.
\end{abstract}

PACS: 78.55.Hx, 81.20. Fw, 29.40.Mc, 73.61.Tm

Keywords: scintillators, borate, sol-gel, medical imaging, x-ray conversion 


\section{Introduction}

Nowadays, research directed towards scintillating materials is in constant development. These materials, that convert high energy radiation into UV-Visible light, are used in various applications: medical imaging, high energy physics, airport security and industrial control. The use of these scintillating materials in medical equipment (X-rays, $\gamma$ rays, positron emission, ... ) requires improvement of their properties, in particular their conversion yield. Soft chemistry routes and in particular the sol-gel process offer an attractive alternative solution for the production of efficient scintillators with a control of the optical properties.

Rare earth activated lutetium orthoborates, which present a high density due to lutetium, appear to be good scintillators [1,2]. We consequently decided to prepare $\mathrm{LuBO}_{3}: \mathrm{Eu}^{3+}$ and $\mathrm{LuBO}_{3}: \mathrm{Tb}^{3+}$ powders by an original sol-gel route. Indeed, the major advantage of this soft chemistry process is that it allows the control of the morphology and the texture of the materials and also the preparation of the material as thin films $[3,4,5]$. Moreover, the sol-gel route allows the elaboration of materials of different composition and doped easily with different ions, in various concentration and the sol-gel derived materials are synthesized at lower temperature than the ones elaborated by classical solid state synthesis.

The powders have been characterized using various techniques. The purity and the morphology have been respectively analysed by X-Ray Diffraction (XRD) and Scanning Electron Microscopy (SEM). The scintillation properties of $\mathrm{LuBO}_{3}: \mathrm{Eu}^{3+}$ and $\mathrm{LuBO}_{3}: \mathrm{Tb}^{3+}$ powders have also been studied.

\section{Experimental section}




\subsection{Powders preparation}

$\mathrm{LuBO}_{3}: \mathrm{Eu}^{3+}$ and $\mathrm{LuBO}_{3}: \mathrm{Tb}^{3+}$ powders have been prepared by a sol-gel process described elsewhere [6]. In a first step, lutetium and Ln (Ln: Eu or Tb) chlorides are dissolved in required amounts in isopropanol during 2 hours. Rare earth chlorides and solvents used were anhydrous and all the experiments were carried out in an argon inert atmosphere to prevent any influence of air moisture.

Potassium isopropoxide was prepared by reacting metallic potassium (Aldrich) with anhydrous 2-propanol (Accros). After dissolution of chlorides, the solution of potassium isopropoxide is added and then $\mathrm{Lu} / \mathrm{Ln}$ chlorides mixture is reacted with the potassium alcoholate which substitutes for chloride leading to the formation of the rare earth alkoxides and the immediate precipitation of $\mathrm{KCl}$ according to:

$$
\mathrm{LnCl}_{3}+3 \mathrm{~K}^{+}+3{ }^{\mathrm{i}} \mathrm{OPr}^{-} \rightarrow \operatorname{Ln}\left({ }^{\mathrm{i}} \mathrm{OPr}\right)_{3}+3 \mathrm{KCl} \downarrow
$$

This mixture was then refluxed for $2 \mathrm{~h}$ at $85^{\circ} \mathrm{C}$, in order to complete the formation of the rare earth alkoxides. Secondly, an alcoholic solution of boron tri-isopropoxide is added. A homogeneous solution is obtained after 4 h-reflux at $85^{\circ} \mathrm{C}$.

After cooling down at room temperature, centrifugation is performed in order to separate $\mathrm{KCl}$ from the sol. The hydrolysis of the sol with distilled water yields a gel, which is dried at $80^{\circ} \mathrm{C}$ to obtain a white xerogel.

This xerogel is then fired at $800^{\circ} \mathrm{C}$ for $18 \mathrm{~h}$ in order to obtain $\mathrm{Lu}_{(1-\mathrm{x})} \mathrm{Ln}_{\mathrm{x}} \mathrm{BO}_{3}(\mathrm{Ln}: \mathrm{Eu}$ or $\mathrm{Tb}$ ) crystalline powders. Samples with $0.005<\mathrm{x}<0.15$ and $0.002<\mathrm{x}<0.05$ have been prepared respectively for $\mathrm{LuBO}_{3}: \mathrm{Eu}^{3+}$ and $\mathrm{LuBO}_{3}: \mathrm{Tb}^{3+}$. 


\subsection{Characterization}

All powders have been checked by X-Ray diffraction on a Siemens D501 diffractometer working in the Bragg-Brentano configuration with $\mathrm{Cu}-\mathrm{K}_{\alpha}$ radiation $(\lambda=$ $1.5406 \AA ̊)$.

Infrared spectra were recorded on a Perkin Elmer 2000 FTIR spectrometer using the $\mathrm{KBr}$ pellet technique.

Thermogravimetric analysis was performed using a Metler Toledo 851 apparatus. Samples were heated in air with a rate of $1^{\circ} \mathrm{C} \cdot \mathrm{min}^{-1}$.

Micrographs were recorded using a Cambridge StereoScan 360 SEM operating at 20 $\mathrm{kV}$. Samples were prepared by depositing a small quantity of powder on adhesive carbon film before coating the surface with gold.

The excitation spectra of all the powders, doped with $\mathrm{Eu}^{3+}$ or $\mathrm{Tb}^{3+}$, were recorded at room temperature using a Xenon lamp as continuous excitation source and a Triax 320 monochromator coupled with a CCD detector.

The scintillation spectra were recorded with a Jobin-Yvon Triax 320 monochromator coupled with a CCD camera after excitation of the samples with a tungsten X-ray tube working at $35 \mathrm{kV}$ and $15 \mathrm{~mA}$. The signal was collected near the sample with an optical fiber. For relative conversion yield estimation, the samples were placed in a quartz tube with a fixed position throughout the measurements. Commercial polycristalline $\mathrm{Gd}_{2} \mathrm{O}_{2} \mathrm{~S}: \mathrm{Tb}^{3+}$ powder supplied by Riedel de Haën was used as a standard for the scintillation yields measurements. The setup was kept constant between the measurements (excitation and detection), simply changing the sample tube. Equivalent masses of samples were used for measurements and all samples were milled in similar conditions in order to keep the granulometry as constant as possible. Reproducibility was tested on the gadox sample yielding values within a $5 \%$ deviation range. 
The afterglow measurements were performed at room temperature on the samples corresponding to concentration optima. The excitation was performed during $10 \mathrm{~s}$ with a Xray source working at $40 \mathrm{kV}$ and $35 \mathrm{~mA} \cdot \mathrm{Gd}_{2} \mathrm{O}_{2} \mathrm{~S}: \mathrm{Tb}^{3+}$ powder was used as a reference.

\section{Results and discussion}

\subsection{Characterisation}

\section{$X$-Ray diffraction}

Figure 1 presents the X-Ray diffraction patterns recorded for $\mathrm{LuBO}_{3}$ powders heated at $800^{\circ} \mathrm{C}$ for $18 \mathrm{~h}$ and doped with $\mathrm{Eu}^{3+}$ (Fig. 1 a) or $\mathrm{Tb}^{3+}$ (Fig. 1 b) ions. Orthoborate $\mathrm{LuBO}_{3}$ presents two crystalline types depending on the thermal treatment. As mentioned in [7] the vaterite form is obtained at $800^{\circ} \mathrm{C}$ instead of the calcite form when the material is prepared by solid state reaction. However, all the recorded diffractograms are identical and show exclusively the vaterite form of $\mathrm{LuBO}_{3}$ with no evidence for $\mathrm{LuBO}_{3}$ calcite, $\mathrm{EuBO}_{3}$ or $\mathrm{TbBO}_{3}$ phases. Refinement of powder X-ray diffraction patterns allows deriving the cell parameters for the vaterite phase of $\mathrm{LuBO}_{3}$. Plot of the cell volume as a function of $\mathrm{Eu}^{3+}$ content as shown in Figure 2, clearly shows a linear evolution as expected from Vegard's Law for a solid solution. So rare earth ions $\left(\mathrm{Eu}^{3+}, \mathrm{Tb}^{3+}\right)$ substitute for $\mathrm{Lu}^{3+}$ cation in $\mathrm{LuBO}_{3}$ vaterite structure and the solid solution is observed up to $15 \%$ and $5 \%$ for respectively europium and terbium ions. Solid solution limits have not been determined and higher concentration might be possible while keeping the vaterite structure and a monophasic material. 


\section{FTIR Spectroscopy}

Fourier transform Infrared spectroscopy has been carried out on the different samples doped with $\mathrm{Eu}^{3+}$ or $\mathrm{Tb}^{3+}$ ions. All recorded spectra, displayed in Figure 3, are similar. No significant change is observed upon doping with $\mathrm{Eu}^{3+}$ (Figure 3(a)) or $\mathrm{Tb}^{3+}$ (Figure 3(b)) ions. All the bands observed in the range $500-1200 \mathrm{~cm}^{-1}$ correspond to B-O group vibration modes and the positions agree well with published results $[4,8]$.

\section{Thermal analysis}

The evolution of $\mathrm{LuBO}_{3}$ from the amorphous to crystalline form has been studied by thermal analysis. This study gives informations on the cristallisation of the material. A thermogravimetric analysis has been carried out on $\mathrm{LuBO}_{3}$ powder elaborated by sol-gel process and the resulting thermogramm is presented in Figure 4. The first derivative is also shown in order to clearly identify the temperatures associated with the different weight losses.

A first weight loss is observed around $100^{\circ} \mathrm{C}$ and can be allotted to the elimination of adsorbed species such as alcohol or water molecules. A second significant weight loss, observed at about $150^{\circ} \mathrm{C}$, corresponds to the condensation of the material. There is a condensation of the alkoxy and hydroxy groups with subsequent alcohol or water elimination. Some residual organic compounds can also be directly pyrolyzed. At this temperature, the inorganic skeleton is formed. A last weight loss is observed at $700^{\circ} \mathrm{C}$ and corresponds to the crystallisation temperature. From this temperature, the crystalline growth occurs and no more weight loss is observed. This last loss is characteristic of the mineral network reorganization and of the final elimination of residual $\mathrm{OH}$ groupments. Total loss of weight is approximately 17\%. Thermal behavior appear very consistent with former results concerning sol-gel derived oxides 


\section{Scanning Electron Microscopy}

To complete the study, Scanning Electron Microscopy has been performed on vaterite $\mathrm{LuBO}_{3}$ powders synthesized by sol-gel process and treated at $800^{\circ} \mathrm{C}$ for $18 \mathrm{~h}$.

The micrograph recorded at $30000 \times$ magnification, given in Figure 5, indicate that $\mathrm{LuBO}_{3}$ powders are homogeneous and constituted of small spherical particles of about $200 \mathrm{~nm}$. The size distribution of these particles is uniform, which is a usual consequence of using the solgel process.

\subsection{Excitation and emission spectra}

\section{Excitation spectra}

The excitation spectra of $\mathrm{LuBO}_{3}: \mathrm{Eu}^{3+}$ and $\mathrm{LuBO}_{3}: \mathrm{Tb}^{3+}$ vaterite powders were recorded for different concentrations of $\mathrm{Eu}^{3+}(0.05<\mathrm{x}<0.15)$ and $\mathrm{Tb}^{3+}(0.002<\mathrm{x}<0.05)$. Figure 6 shows the excitation spectra recorded at room temperature by fixing the emission wavelength at respectively $591 \mathrm{~nm}$ and $541 \mathrm{~nm}$ for the optima $\left(\mathrm{Lu}_{0.95} \mathrm{Eu}_{0.05} \mathrm{BO}_{3}\right.$ and $\left.\mathrm{Lu}_{0.95} \mathrm{~Tb}_{0.0} 5 \mathrm{BO}_{3}\right)$.

The excitation spectrum recorded for $\mathrm{LuBO}_{3}: \mathrm{Eu}^{3+}$ powder is constituted of lines corresponding to $4 \mathrm{f}-4 \mathrm{f}$ transitions. The line observed at about $470 \mathrm{~nm}$ is attributed to ${ }^{7} \mathrm{~F}_{0} \rightarrow$ ${ }^{5} \mathrm{D}_{2}$ transition and the ones situated in the range between $300-430 \mathrm{~nm}$ correspond to ${ }^{7} \mathrm{~F}_{0} \rightarrow$ ${ }^{5} \mathrm{~F}_{2},{ }^{5} \mathrm{H}_{\mathrm{J}},{ }^{5} \mathrm{D}_{4},{ }^{5} \mathrm{G}_{\mathrm{J}},{ }^{5} \mathrm{~L}_{8},{ }^{5} \mathrm{~L}_{6},{ }^{5} \mathrm{D}_{3}$ transitions. The excitation band located below $250 \mathrm{~nm}$ is assigned to the charge transfer absorption [9].

The excitation lines observed for $\mathrm{LuBO}_{3}: \mathrm{Tb}^{3+}$ powder, in the range $300-500 \mathrm{~nm}$, are characteristic of $4 \mathrm{f}-4 \mathrm{f}$ transitions. They correspond to ${ }^{7} \mathrm{~F}_{6} \rightarrow{ }^{5} \mathrm{H}_{6},{ }^{5} \mathrm{H}_{7},{ }^{5} \mathrm{~L}_{8},{ }^{5} \mathrm{~L}_{9},{ }^{5} \mathrm{D}_{2},{ }^{5} \mathrm{G}_{5},{ }^{5} \mathrm{~L}_{10}$, ${ }^{5} \mathrm{G}_{6},{ }^{5} \mathrm{D}_{3}$ and ${ }^{5} \mathrm{D}_{4}$ transitions [10]. 


\section{Emission spectra}

The emission spectra recorded at room temperature under X-ray excitation for $\mathrm{Eu}^{3+}$ and $\mathrm{Tb}^{3+}$ doped $\mathrm{LuBO}_{3}$ vaterite, with different concentrations of $\mathrm{Eu}^{3+}$ and $\mathrm{Tb}^{3+}$, are presented in Figure 7. Gadox $\left(\mathrm{Gd}_{2} \mathrm{O}_{2} \mathrm{~S}\right.$ : Tb) emission spectrum has also been recorded in order to calculate the scintillation yields of $\mathrm{Eu}$ and $\mathrm{Tb}$ doped materials.

In the case of $\mathrm{LuBO}_{3}: \mathrm{Eu}^{3+}$ (Fig. 7a), the spectrum is constituted of lines corresponding to ${ }^{5} \mathrm{D}_{0} \rightarrow{ }^{7} \mathrm{~F}_{\mathrm{J}(\mathrm{J}=0-4)}$ transitions of $\mathrm{Eu}^{3+}$ ions. The spectral distribution of the $\mathrm{Eu}^{3+}$ doped materials results in a global orange-red emission.

$\mathrm{LuBO}_{3}: \mathrm{Tb}^{3+}$ emission spectrum (Fig. 7b) exhibits, in the range between $475-650 \mathrm{~nm}$, several lines characteristic of ${ }^{5} \mathrm{D}_{4} \rightarrow{ }^{7} \mathrm{~F}_{\mathrm{J}(\mathrm{J}=3-6)}$ transitions of $\mathrm{Tb}^{3+}$ ions. ${ }^{5} \mathrm{D}_{4} \rightarrow{ }^{7} \mathrm{~F}_{5}$ transition is the most intense and confers to the materials an overall green emission.

\section{Scintillation yields}

Scintillation yields have been calculated for all the powders by comparing the integrating areas of the emission spectra of the sample and Gadox. Scintillation yields under $\gamma$-rays excitation is 78000 photons/Mev [11] for Gadox. The yields of our materials were calculated from reference values, which are obtained under $\gamma$-ray excitation. Our measurements have been performed under X-ray excitation, so the results given for the scintillation yields under $\gamma$-ray excitation might be under-estimated. Yields have been calculated for concentrations of $\mathrm{Eu}^{3+}$ and $\mathrm{Tb}^{3+}$ ions with respectively $0.005<\mathrm{x}<0.15$ and $0.002<\mathrm{x}<0.05$. The scintillation yields for all the samples and their evolution as a fonction of the doping ion concentration is presented in Figure 8. 
For $\mathrm{Eu}^{3+}$ doped $\mathrm{LuBO}_{3}$, the optimum is obtained for a Eu concentration of $5 \%$ with a scintillation yield of about 8923 photons/MeV. This scintillation yield is $11 \%$ of the Gadox one, which is a good value.

In the case of $\mathrm{Tb}^{3+}$ doped $\mathrm{LuBO}_{3}$ powders, $\mathrm{LuBO}_{3}: \mathrm{Tb}^{3+}(5 \%)$ present the higher scintillation yield since this one is equal to about 4398 photons $/ \mathrm{MeV}$.

\subsection{Afterglow}

Precise knowledge of the afterglow is required for practical applications. Afterglow measurements were recorded at room temperature, using an X-Ray source, which operated at $40 \mathrm{kV}$ with an intensity of $25 \mathrm{~mA}$. The material was excited for $10 \mathrm{~s}$ and the signal was collected using a photomultiplier.

The afterglow behaviours for $\mathrm{Eu}^{3+}$ and $\mathrm{Tb}^{3+}$ doped $\mathrm{LuBO}_{3}$ powders are presented in Figure 9. The afterglow of Gadox $\left(\mathrm{Gd}_{2} \mathrm{O}_{2} \mathrm{~S}: \mathrm{Tb}^{3+}\right)$ was also measured as a reference. The afterglow values, mesured $1 \mathrm{~s}$ after X-ray turn-off, are $1 \%, 0.2 \%$ and $0.007 \%$ respectively for $\mathrm{Lu}_{0.95} \mathrm{Eu}_{0.05} \mathrm{BO}_{3}, \mathrm{Lu}_{0.95} \mathrm{~Tb}_{0.05} \mathrm{BO}_{3}$ and Gadox.

\section{Conclusion}

The sol-gel process has been proven to be a good technique for the preparation of scintillating materials doped with different rare earth ions both as powders and thin films. The advantages of this method compared to traditional syntheses are, the lower temperature of treatment, the good crystallinity and purity of the samples, the morphology control and a homogeneous distribution of the particles size. 
The scintillation properties of $\mathrm{Eu}^{3+}$ and $\mathrm{Tb}^{3+}$ doped $\mathrm{LuBO}_{3}$ powders were studied for different concentrations of doping ion and good scintillation yields were obtained.

Sol-gel derived $\mathrm{LuBO}_{3}: \mathrm{Eu}^{3+}$ and $\mathrm{LuBO}_{3}: \mathrm{Tb}^{3+}$ appear to be promising scintillators.

\section{Acknowledgements}

The authors would like to thanks the French FRT for financial support under project LuminiX (RNTS-01B262).

\section{Figures captions}

Figures captions

Figure 1: X-Ray diffraction patterns recorded for (a) $\mathrm{Lu}_{0.85} \mathrm{Eu}_{0.15} \mathrm{BO}_{3}$ and (b) $\mathrm{Lu}_{0.95} \mathrm{~Tb}_{0.05} \mathrm{BO}_{3}$ with the corresponding ASTM reference patterns (dotted lines)

Figure 2: Evolution of the unit cell volume for $\mathrm{Lu}_{1-\mathrm{x}} \mathrm{Eu}_{\mathrm{x}} \mathrm{BO}_{3} \mathrm{x}=0-0.15$ as a function of $\mathrm{x}$. Figure 3: IRTF spectra of (a) $\mathrm{LuBO}_{3}: \mathrm{Eu}^{3+}$ and (b) $\mathrm{LuBO}_{3}: \mathrm{Tb}^{3+}$ powders of vaterite form heated at $800^{\circ} \mathrm{C}$ for $18 \mathrm{~h}$

Figure 4: TG curve obtained from $\mathrm{LuBO}_{3}$ powder and first derivative curve (dotted line)

Figure 5: SEM micrographs of $\mathrm{LuBO}_{3}$ samples of vaterite form heated at $800^{\circ} \mathrm{C}$ for $18 \mathrm{~h}$

Figure 6: Excitation spectra of (a) $\mathrm{LuBO}_{3}: \mathrm{Eu}^{3+}$ and (b) $\mathrm{LuBO}_{3}: \mathrm{Tb}^{3+}$ of vaterite form for different concentrations of $\mathrm{Eu}^{3+}(0.005<\mathrm{x}<0.15)$ and $\mathrm{Tb}^{3+}(0.002<\mathrm{x}<0.05)$ recorded at respectively $\lambda_{\mathrm{em}}=591 \mathrm{~nm}$ and $\lambda_{\mathrm{em}}=541 \mathrm{~nm}$ and at room temperature

Figure 7: Emission spectra recorded, at room temperature, under X-ray excitation on (a) $\mathrm{LuBO}_{3}: \mathrm{Eu}^{3+}$ and (b) $\mathrm{LuBO}_{3}: \mathrm{Tb}^{3+}$ of vaterite form, with different concentrations of $\mathrm{Eu}^{3+}$ and $\mathrm{Tb}^{3+}$ ions.

Figure 8: Relative scintillation yields of (a) $\mathrm{LuBO}_{3}: \mathrm{Eu}^{3+}$ and (b) $\mathrm{LuBO}_{3}: \mathrm{Tb}^{3+}$ powders 
Figure 9: Afterglow measurement on $\mathrm{Lu}_{0.95} \mathrm{Eu}_{0.05} \mathrm{BO}_{3}, \mathrm{Lu}_{0.95} \mathrm{~Tb}_{0.05} \mathrm{BO}_{3}$ and Gadox under $\mathrm{X}$ ray excitation with a $10 \mathrm{~s}$ irradiation time. 


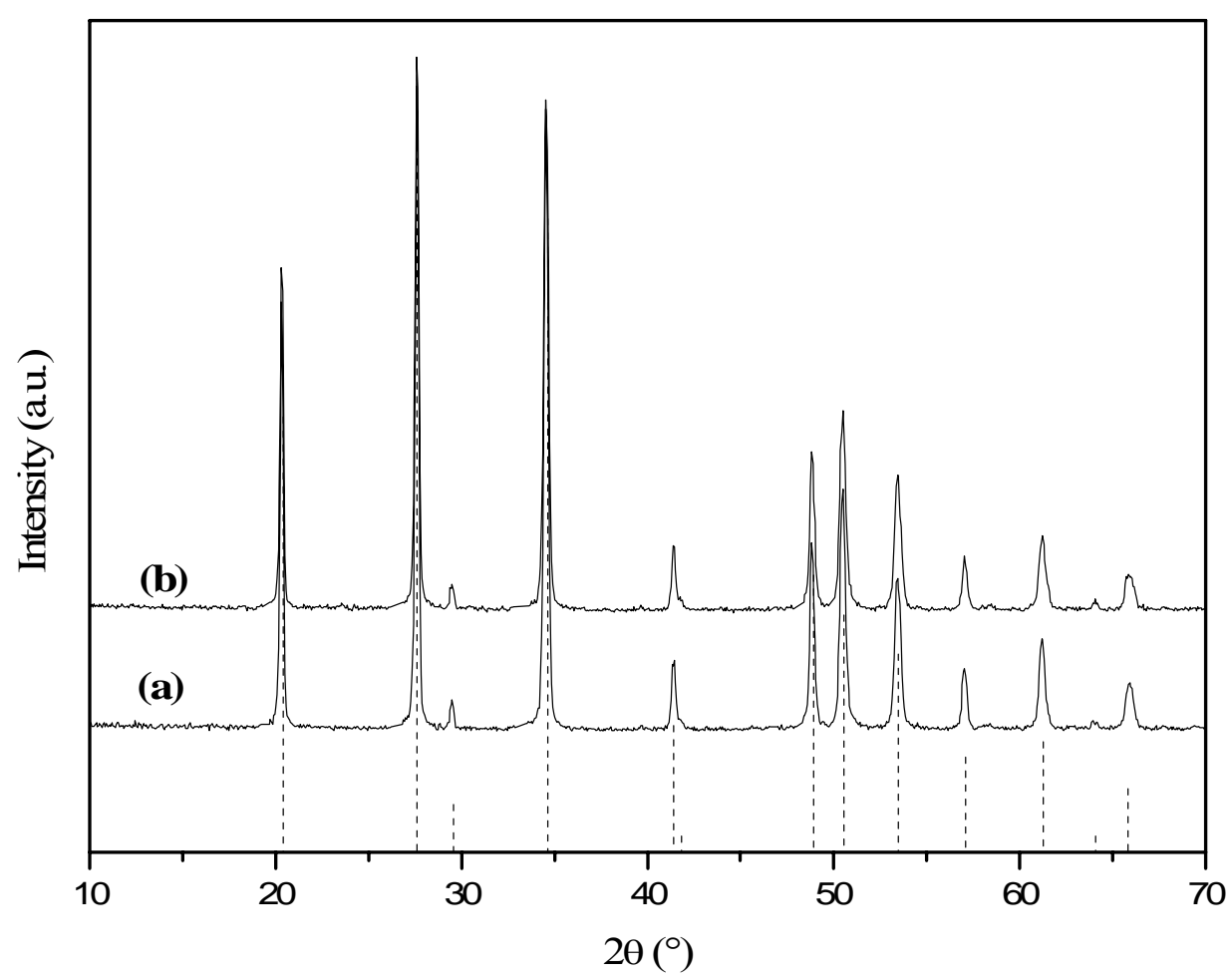

Figure 1: X-Ray diffraction patterns recorded for (a) $\mathrm{Lu}_{0.85} \mathrm{Eu}_{0.15} \mathrm{BO}_{3}$ and (b) $\mathrm{Lu}_{0.95} \mathrm{~Tb}_{0.05} \mathrm{BO}_{3}$ with the corresponding ASTM reference patterns (dotted lines)

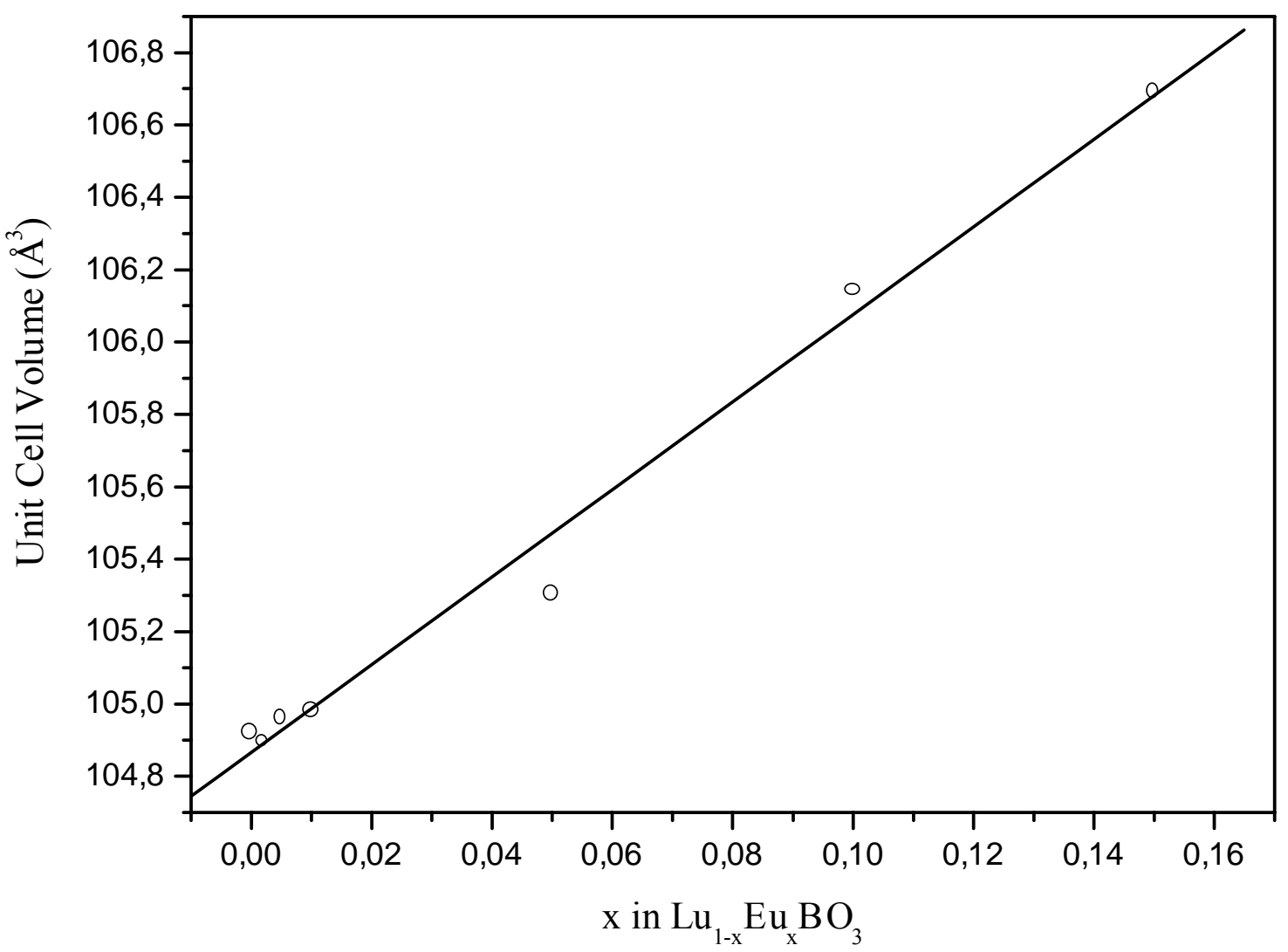

Figure 2: Evolution of the unit cell volume for $\mathrm{Lu}_{1-\mathrm{x}} \mathrm{Eu}_{\mathrm{x}} \mathrm{BO}_{3} \mathrm{x}=0-0.15$ as a function of $\mathrm{x}$. 

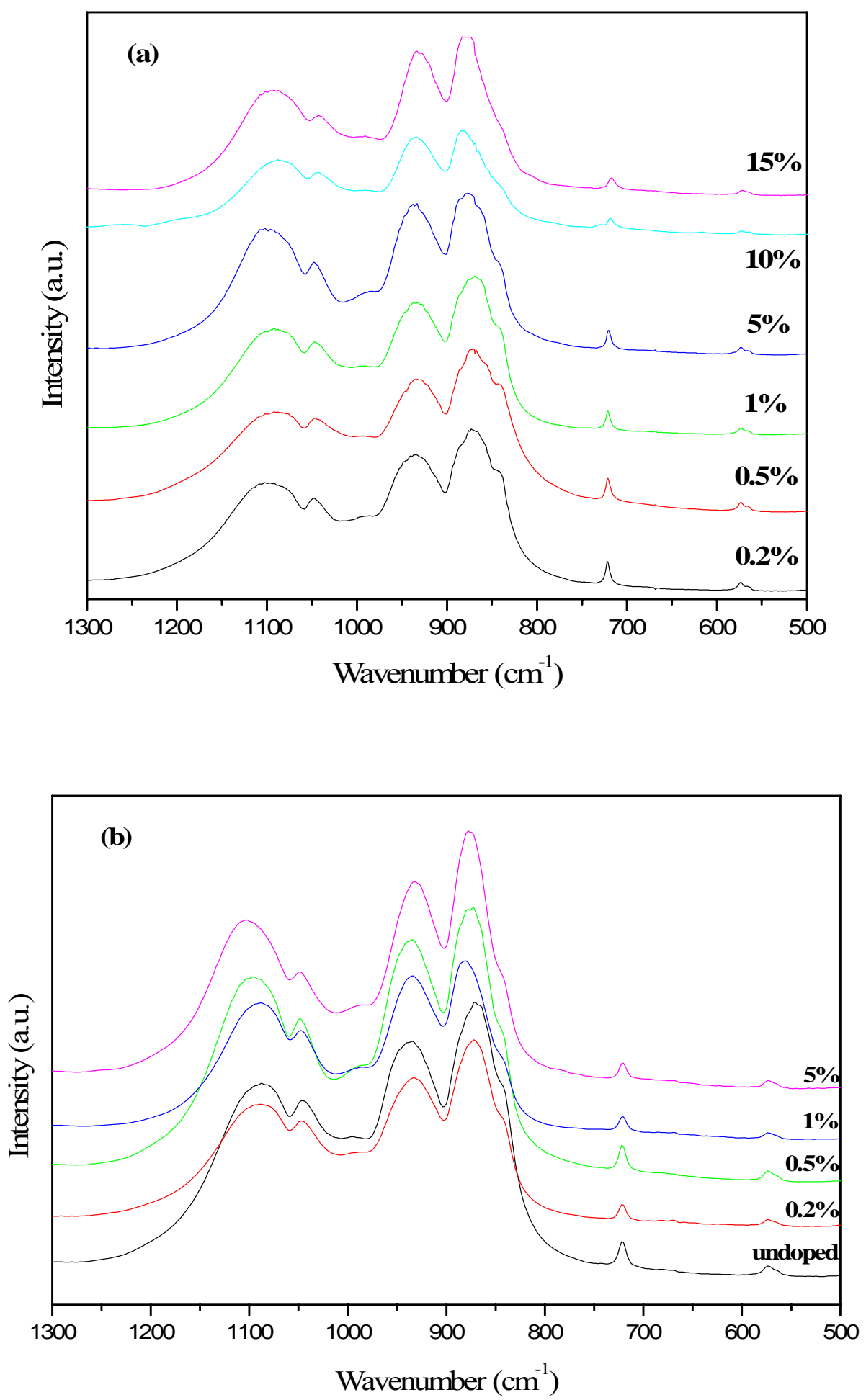

Figure 3: IRTF spectra of (a) $\mathrm{LuBO}_{3}: \mathrm{Eu}^{3+}$ and (b) $\mathrm{LuBO}_{3}: \mathrm{Tb}^{3+}$ powders of vaterite form heated at $800^{\circ} \mathrm{C}$ for $18 \mathrm{~h}$ 


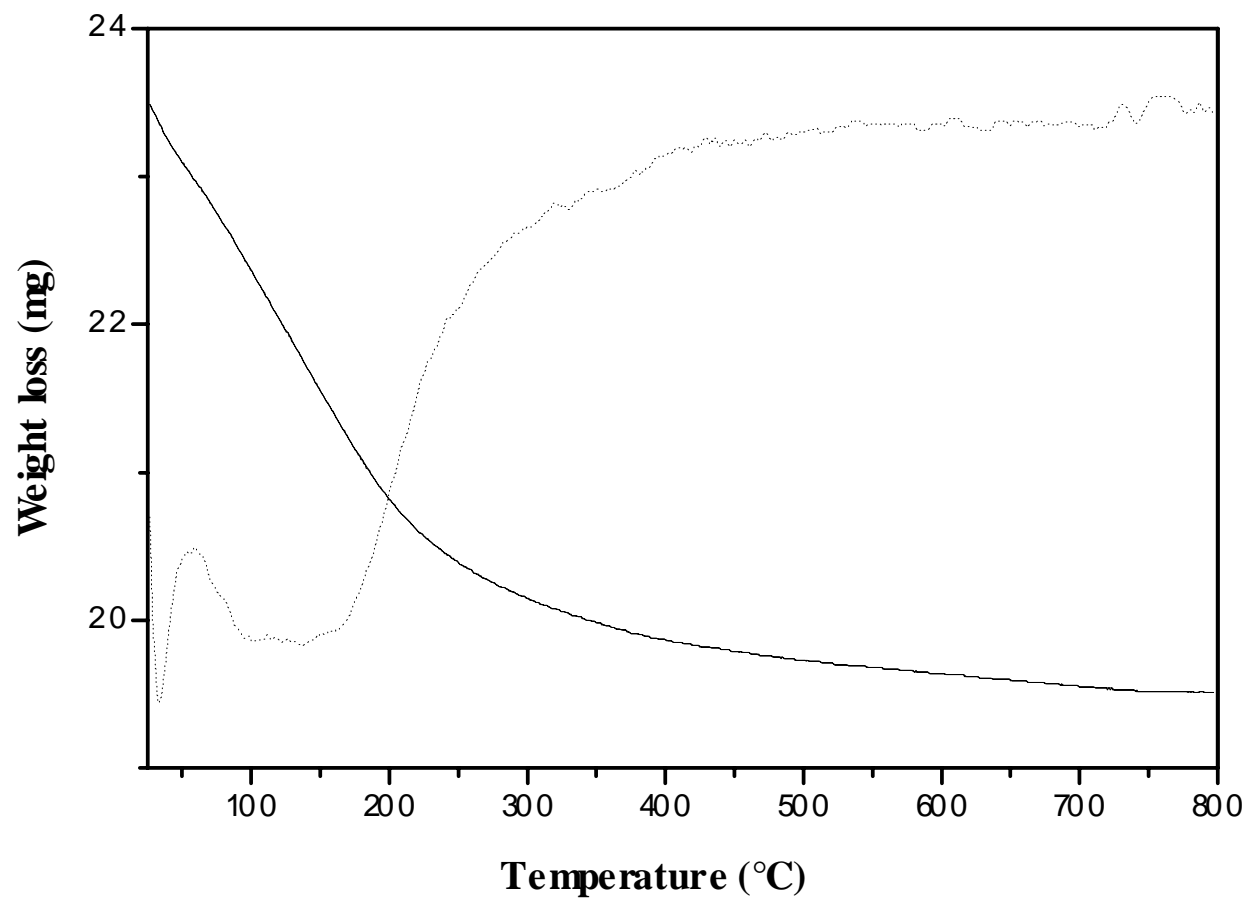

Figure 4: TG curve obtained from $\mathrm{LuBO}_{3}$ powder and first derivative curve (dotted line) 


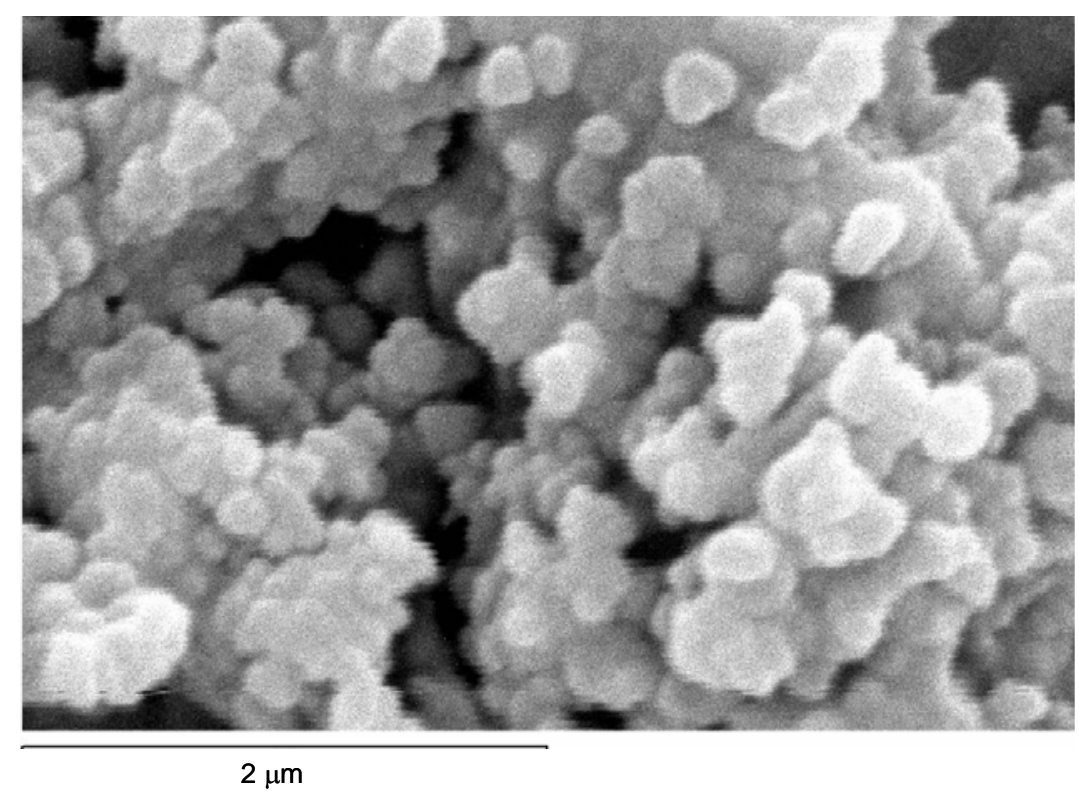

Figure 5: SEM micrographs of $\mathrm{LuBO}_{3}$ samples of vaterite form heated at $800^{\circ} \mathrm{C}$ for $18 \mathrm{~h}$ 

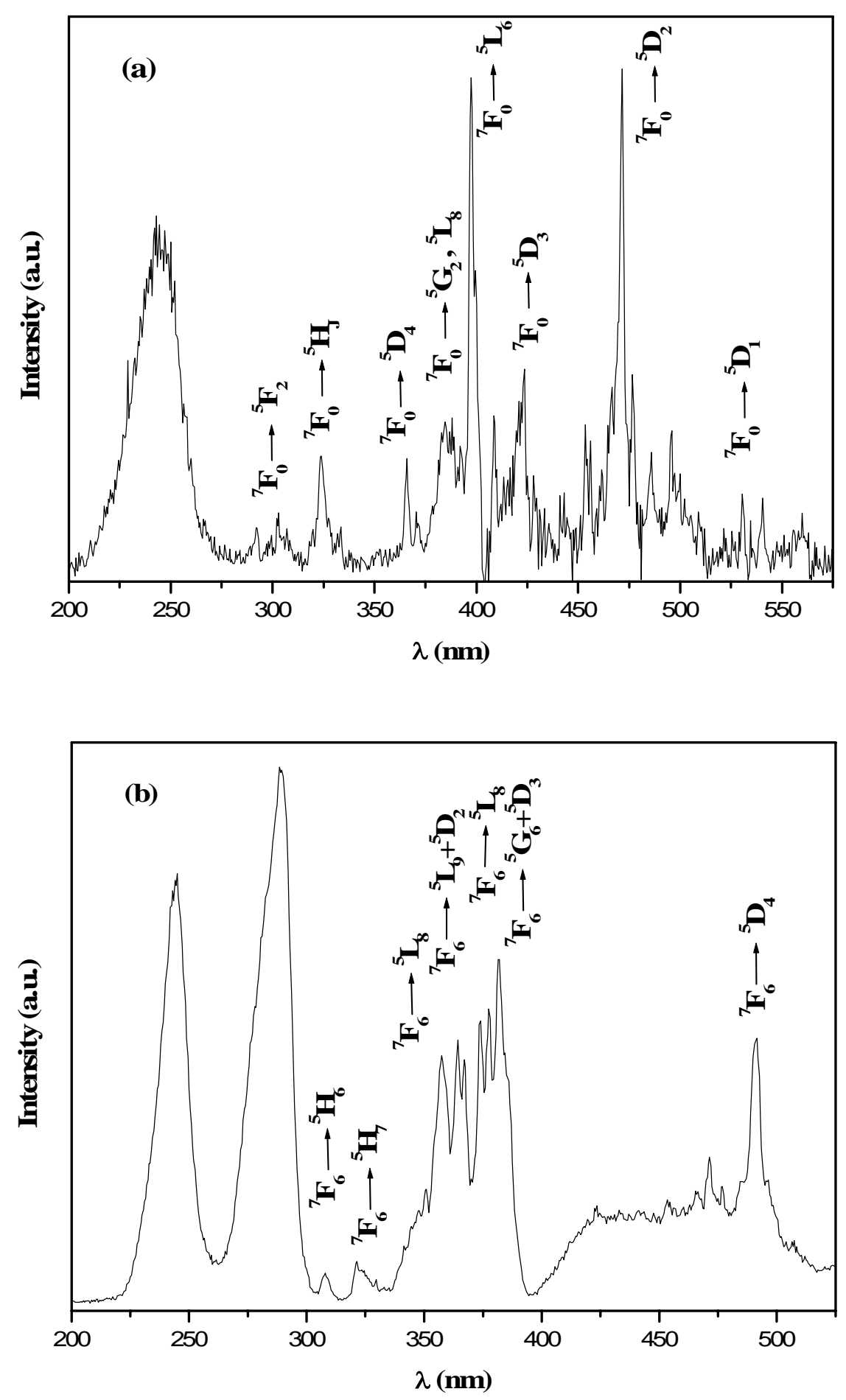

Figure 6: Excitation spectra of (a) $\mathrm{LuBO}_{3}: \mathrm{Eu}^{3+}$ and (b) $\mathrm{LuBO}_{3}: \mathrm{Tb}^{3+}$ of vaterite form for different concentrations of $\mathrm{Eu}^{3+}(0.005<\mathrm{x}<0.15)$ and $\mathrm{Tb}^{3+}(0.002<\mathrm{x}<0.05)$ recorded at respectively $\lambda_{\mathrm{em}}=$ $591 \mathrm{~nm}$ and $\lambda_{\text {em }}=541 \mathrm{~nm}$ and at room temperature 

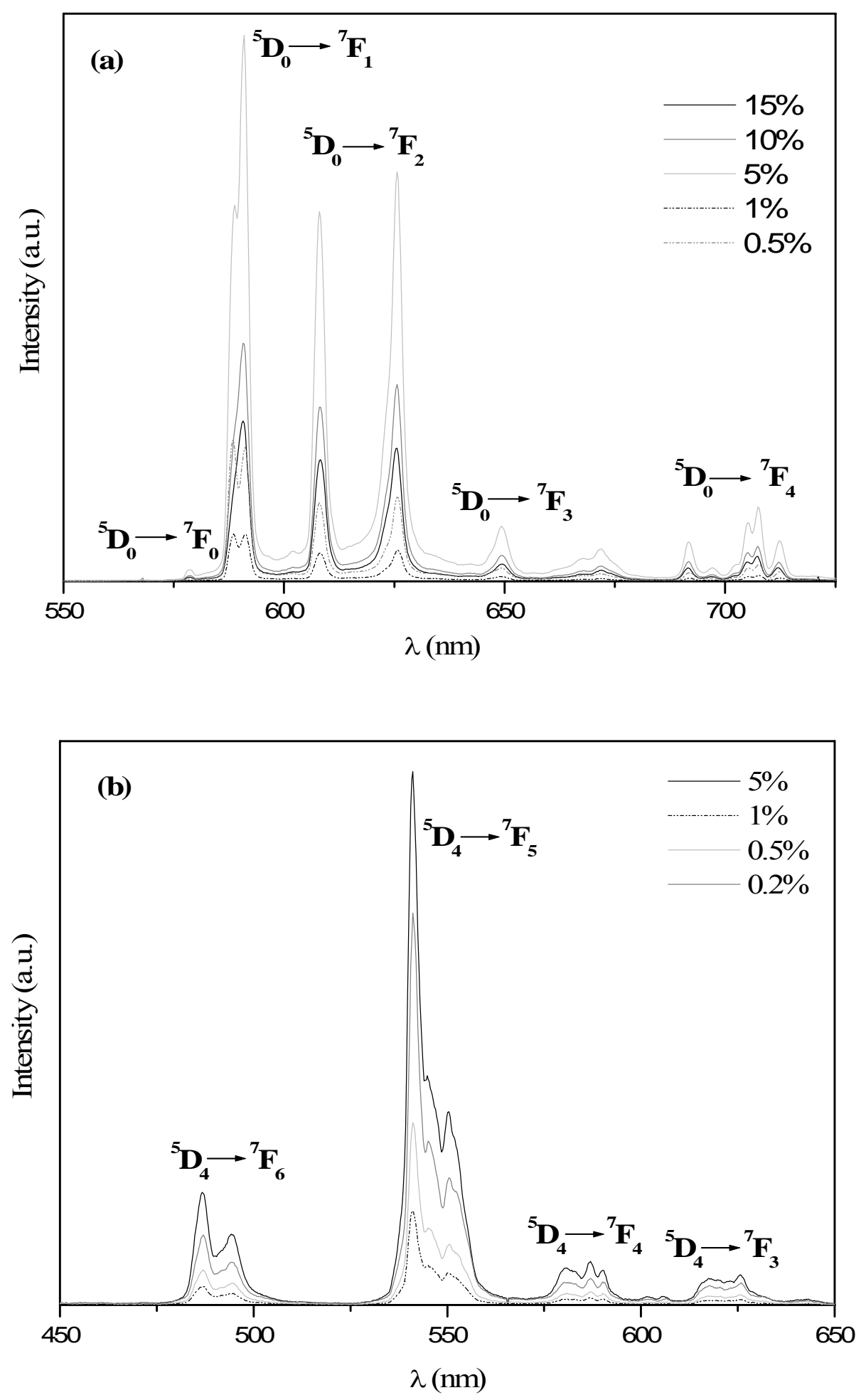

Figure 7: Emission spectra recorded, at room temperature, under X-ray excitation on (a) $\mathrm{LuBO}_{3}: \mathrm{Eu}^{3+}$ and (b) $\mathrm{LuBO}_{3}: \mathrm{Tb}^{3+}$ of vaterite form, with different concentrations of $\mathrm{Eu}^{3+}$ and $\mathrm{Tb}^{3+}$ ions. 

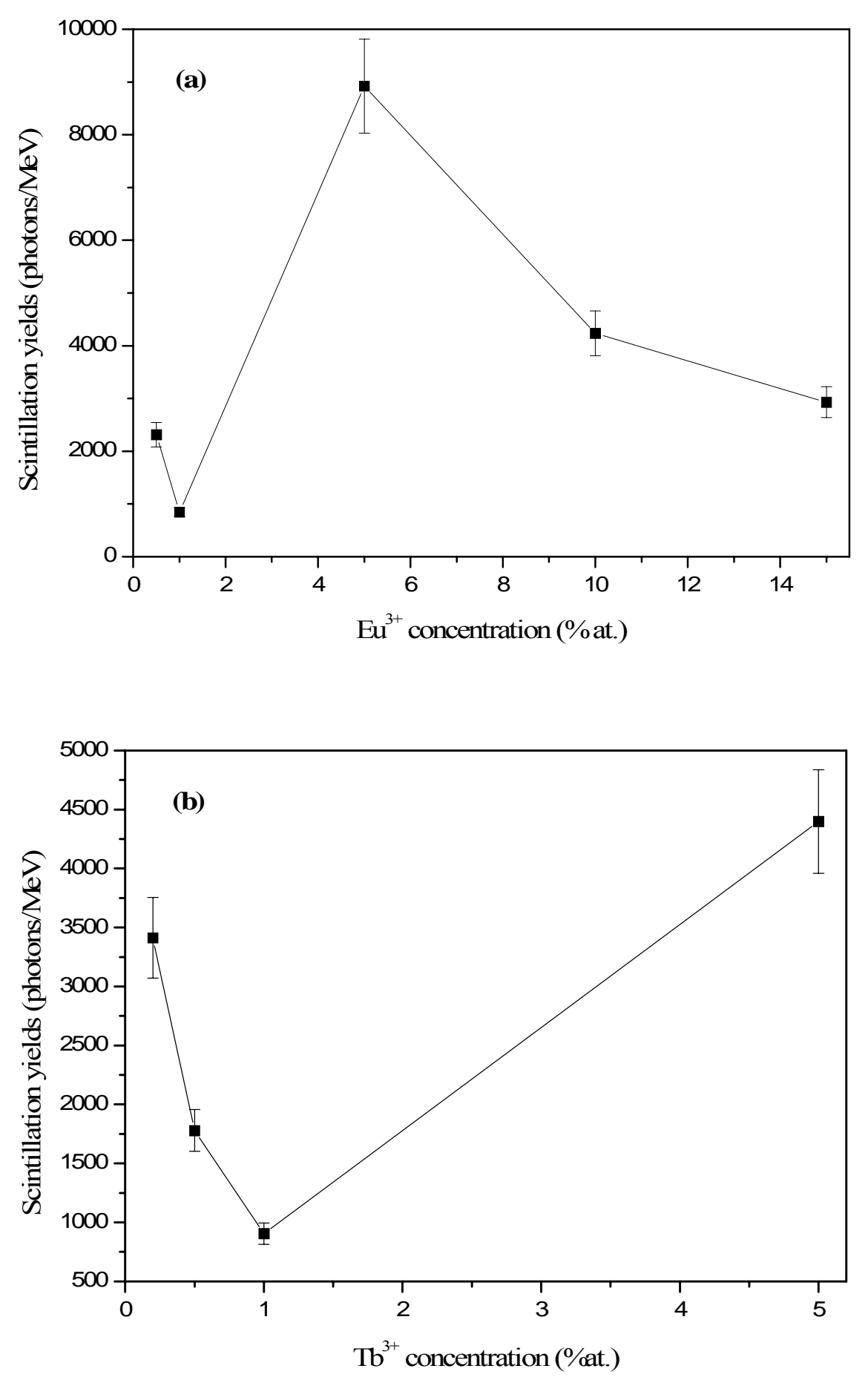

Figure 8: Relative scintillation yields of (a) $\mathrm{LuBO}_{3}: \mathrm{Eu}^{3+}$ and (b) $\mathrm{LuBO}_{3}: \mathrm{Tb}^{3+}$ powders. 


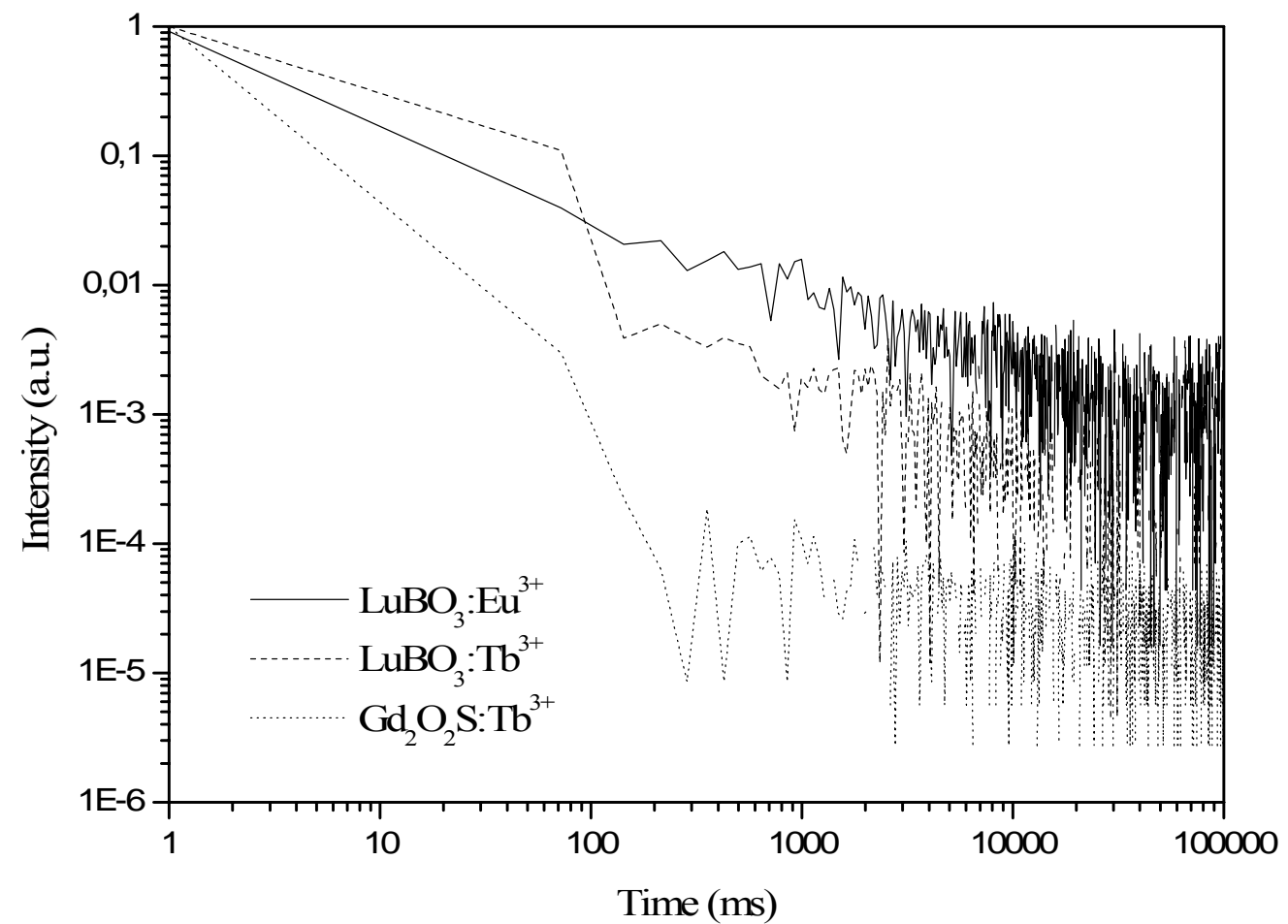

Figure 9: Afterglow measurement on $\mathrm{Lu}_{0.95} \mathrm{Eu}_{0.05} \mathrm{BO}_{3}, \mathrm{Lu}_{0.95} \mathrm{~Tb}_{0.05} \mathrm{BO}_{3}$ and Gadox under X-ray excitation with a $10 \mathrm{~s}$ irradiation time. 


\section{References}

[1] L. Zhang, C. Pedrini, C. Madej, C. Dujardin, J.C. Gâcon, B. Moine, I. Kamenskikh, A. Belsky, D.A. Shaw, M.A. MacDonald, P. Mesnard, C. Fouassier, J.C. Van't Spijker and C.E.W. Van Eijk, Radiation Effects and Defects in Solids, 1999, 150(1-4), 439.

[2] W.W.Moses, M.J.Weber, S.E.Derenzo, D.Perry and P.Berdahl, Procceding of the International Conference on Inorganic Scintillators and Their Applications, September 22-25, 1997.

[3] H. Schmidt, M. Mennig, http://www.solgel.com/articles/Default.htm

[4] J.-M. Nedelec, D. Avignant, R. Mahiou, Chem. Mat., 2002, 14, 651.

[5] A. Garcia-Murillo, C. Le Luyer-Urlacher, C. Dujardin, C. Pedrini, J. Mugnier, J. Sol-Gel Sci. Techn., 2003, 26, 957.

[6] D. Boyer, G. Bertrand-Chadeyron, R. Mahiou, L. Lou, A. Brioude, J. Mugnier, Opt. Mater., 2001, 16, 21.

[7] D. Boyer, F. Leroux, G. Bertrand, R. Mahiou, J. Non-Cryst. Solids, 2002, 306, 110.

[8] C.E. Weir, R.A. Schröeder, J. Res. Nat. Bur. Stand., 1964, 68A, 465. G. Chadeyron, M.

El-Ghozzi, R. Mahiou, A. Arbus and J. C. Cousseins, J. Solid State Chem., 1997, 128, 261. 
[9] D. Hreniak, E. Zych, L. Kepinski and W. Strek, J. Phys. Chem. Solids, 2003, 64, 111.

[10] M. Zawadzki, D. Hreniak, J. Wrzyszcz, W. Mista, H. Grabowska, O.L. Malta et W. Strek, Chem. Phys., 2003, 291 (3), 275.

[11] L.H. Brixner, Mat. Chem. Phys., 1987, 16, 253. 